\title{
The Financial Crisis - a Microfinance Perspective
}
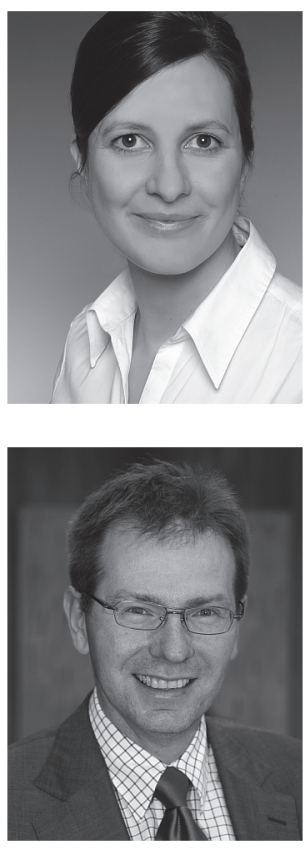

ly a rising degree of competition and integration.

Die Finanzkrise löste eine Diskussion über die Rolle von finance in Marktwirtschaften aus. Hat ein entwickeltes Finanzsystem wirklich nur positive Wirkungen für Wachstum und Entwicklung, oder gibt es auch Gefahren? Diese Diskussion hat auch die Mikrofinanzierung erreicht, nicht zuletzt weil sie zum ersten Mal einen ausgeprägten Kreditzyklus aufweist: Dem credit boom in der Vorkrisenperiode folgte ein starker Rückgang des Kreditwachstums in den Krisenjahren 2008-2009. Dieser Beitrag zeigt auf der einen Seite, dass Mikrofinanzierung zwar weitgehend gegen jene Stabilitätsrisiken immun ist, die bei der Vergabe zweitklassiger Hypothekendarlehen in den USA, dem Auslöser der globalen Finanzkrise, entstanden. Denn die Kredittechnologie der Mikrofinanzierung setzt am ,cash-flow' des Kreditnehmers an, während subprime lending auf eine positive Wertentwicklung des Hauses setzte. Auf der anderen Seite jedoch ist der Mikrofinanzsektor in einem Marktumfeld, das durch zunehmende finanzielle Integration und Wettbewerb gekennzeichnet ist, den Risiken einer exzessiven Kreditvergabe in ähnlichem Masse ausgesetzt wie der traditionelle Finanzsektor.

\section{Introduction}

The global financial crisis has led to a reassessment of the role of finance in modern economies. This does not only hold for mature economies where the crisis originated (see e.g. Trichet 2010; Bernanke 2012), but also for emerging markets and developing coun- 
tries. As a result, the long-standing view that "finance is good for growth and development" (King/Levine 1992) has been challenged and qualified: there can be too much of a good thing, in particular if financial deepening raises the likelihood of financial turmoil with the associated negative impact on output and employment (see de la Torre et al. 2011; Rousseau/Wachtel 2011; Arcand et al. 2012; Cecchetti/Kharroubi 2012).

In the 1990s microfinance emerged as the most popular instrument in development finance, and in the mid-2000s, i.e. thirty years after the first modern microfinance institutions had been founded in Asia and Latin America (Helms 2006), the idea that financial inclusion brings major benefits in terms of poverty alleviation, growth and development was almost universally embraced (for an overview see World Bank 2008). The award of the Nobel Peace Prize for Muhammad Yunus in 2006 represented the peak of microfinance popularity and recognition.

But times have changed for microfinance as well. Today, many see microfinance in a state of crisis. ${ }^{1}$ This perception is nurtured by evidence suggesting that microfinance has failed in delivering on the promise of alleviating poverty among its clients. Modern impact studies seem to suggest that the developmental impact of microfinance is small at best. At the same time, there is increasing evidence of over-indebtedness among microfinance borrowers, placing an additional burden on the poor. Terberger (2012, in this issue) provides a critical review of the debate on impact and over-indebtedness.

In this paper we analyze financial stability aspects of microfinance against the background of the global financial crisis that started in 2007. In doing this, we focus on two aspects that are said to have triggered or caused the global financial crisis, ${ }^{2}$ namely the rise of subprime mortgage lending in the US (see for example Calomiris 2008; Gorton 2008), and the credit boom that has characterized many mature and emerging market economies in the pre-crisis period (IMF 2004). We raise two questions. First, is microfinance similar to subprime lending? Second, is microfinance immune to boom-bust cycles observed in traditional finance?

We show that conceptually microfinance is the exact opposite of subprime lending even though both focus on target groups that do not have access to traditional banking services. Indeed, we argue that if subprime lending had employed at least some elements of the credit technologies characterizing micro lending, this market segment would most likely not have triggered a global financial crisis. However, we also find that microfinance has become more similar to traditional finance by closely following the boom-bust pattern of credit growth. This new development reflects a rising degree of integration of microfinance into mainstream finance. Accordingly, the peculiar characteristics of microfinance compared to traditional finance do not protect the industry from boom-bust cycles.

The paper is structured as follows. We start with a review of arguments suggesting that microfinance is different from traditional finance with a special emphasis on financial crises (section 2). In section 3 we show that one of those differences, i.e. the credit technologies employed, is key for arguing that microfinance is almost the exact opposite to

1 Lützenkirchen/Weistroffer (2012) provide a rather balanced assessment, referring to microfinance as "an industry between crisis and advancement".

2 Our choice reflects the research agenda pursued by the Center of Development Finance at the Frankfurt School of Finance \& Management over the last years; see Winkler (2009) on which Section 3 is based, and Wagner (2012) as well as Wagner/Winkler $(2011,2012)$ who focus on the issues discussed in Section 4. 
subprime lending. This holds despite of both forms of lending targeting poorer households in the respective economies. In Section 4 we argue that the market environment in which microfinance institutions (MFIs) and their clients operate has changed substantially since the early 2000s. These changes have made microfinance more sensitive to business cycle dynamics. As a result, microfinance - despite its continuing differences to traditional banking - has become more vulnerable to financial turmoil. Section 5 summarizes and concludes.

\section{Microfinance, traditional finance, and financial crises}

Why is microfinance different from financial services provided by traditional banks? A first argument relates - as indicated by the term microfinance - to differences in the lot size of financial services offered and demanded: microcredit, microsavings, microinsurance, micro transfers involve smaller volumes than those offered in the traditional banking sector (Table 1). Those size differences have economic implications as the production functions of most financial services exhibit economies of scale which provide larger scale transactions with a profit advantage compared to micro transactions (Helms 2006). As a result, traditional commercial banks do not engage in microfinance transactions. This explains why - after several failed attempts to reach the target group via state-owned development banks - in the early days of microfinance non-governmental organizations (NGOs) emerged as the major providers of microfinance services, in those days almost exclusively microcredit.

A second key difference between micro- and traditional finance, notably between microcredit and a traditional bank loan, relates to the peculiar credit technologies MFIs employ. Group lending and the unconventional individual credit technology were key innovations. ${ }^{3}$ They have allowed MFIs to issue loans to people, poor households as well as micro and small businesses in developing and emerging market economies, that are unable to provide documents and assets traditional banks rely upon when providing loans to their customers. $^{4}$

Most people, however, are likely to argue that the main difference between microfinance and traditional finance is the former's developmental impact, i.e. its ability to lift people out of poverty. This proposition is grounded in three interrelated arguments: First, traditional banks were neither able nor willing to serve poor people. Accordingly, a lack of access to formal financial sector services represented a major difference in opportunities available to microbusinesses and poor households on the one hand, and medium and large enterprises or more wealthy households on the other hand. Second, access to financial services is important from a development point of view as the financial system performs an allocative function in a market economy by providing funds to people with higher returns to capital than those that deposit funds at financial intermediaries and markets (Bodie/ Merton 1995). Third, providing financial access to poor people is expected to yield substantial benefits as - following one of the most basic economic propositions, namely the law of declining marginal returns to capital - the capital-poor can be assumed to have in-

3 From an academic point of view those technologies form the basis for the specific "economics of microfinance" that even justify the publication of a textbook solely devoted to the industry (Armendáriz) Morduch 2010).

4 To a signifcant extent this also reflects the fact that a large part of micro and small businesses in developing countries operate in the informal sector of the respective economies. 
vestment opportunities with high marginal returns (Karlan/Morduch 2012). These three arguments together lead to the conclusion that providing finance to poor households will lead to sizeable income generating effects at the individual client level, allowing them to escape from poverty when having access to those services.

\begin{tabular}{|c|c|c|c|c|}
\hline & Lot size & $\begin{array}{l}\text { Credit } \\
\text { technologies }\end{array}$ & $\begin{array}{l}\text { Development } \\
\text { impact }\end{array}$ & $\begin{array}{l}\text { Vulnerability to } \\
\text { financial turmoil }\end{array}$ \\
\hline $\begin{array}{l}\text { Traditional } \\
\text { finance }\end{array}$ & $\begin{array}{l}\text { Small, medium, } \\
\text { large }\end{array}$ & $\begin{array}{l}\text { Document and } \\
\text { asset based }\end{array}$ & $\begin{array}{c}\text { Positive (finance } \\
\text { and growth liter- } \\
\text { ature) }\end{array}$ & High \\
\hline Microfinance & Micro & $\begin{array}{l}\text { Group lending } \\
\text { and unconven- } \\
\text { tional individual } \\
\text { lending (cash- } \\
\text { flow and person- } \\
\text { ality based) }\end{array}$ & $\begin{array}{l}\text { Extraordinarily } \\
\text { high (due to } \\
\text { high marginal } \\
\text { returns of invest- } \\
\text { ment opportuni- } \\
\text { ties available to } \\
\text { poor people) }\end{array}$ & $\begin{array}{l}\text { Empirical evi- } \\
\text { dence until } \\
\text { 2007: basically } \\
\text { non-existent }\end{array}$ \\
\hline Implication & $\begin{array}{l}\text { Microfinance is } \\
\text { less profitable } \\
\text { than traditional } \\
\text { finance. Thus, } \\
\text { commercial } \\
\text { banks do not of- } \\
\text { fer microfinance } \\
\text { services. }\end{array}$ & $\begin{array}{l}\text { Traditional } \\
\text { banks do not } \\
\text { know how to } \\
\text { serve poor peo- } \\
\text { ple. MFIs, em- } \\
\text { ploying the re- } \\
\text { spective credit } \\
\text { technologies } \\
\text { have to be set } \\
\text { up. }\end{array}$ & $\begin{array}{c}\text { Microfinance } \\
\text { represents an } \\
\text { important tool } \\
\text { of development } \\
\text { policy }\end{array}$ & $\begin{array}{l}\text { Microfinance is } \\
\text { a more stable } \\
\text { source of finance } \\
\text { than traditional } \\
\text { finance }\end{array}$ \\
\hline
\end{tabular}

Table 1: Microfinance versus traditional finance - differences (Source: authors' compilation)

The success of microfinance celebrated in the mid-2000s was largely based on anecdotal evidence suggesting that microfinance clients record substantial income gains. Furthermore, the credit technologies mentioned above had proven their ability to provide loans to the target group with surprisingly low risk costs for the microfinance institutions (Cull et al. 2008; O’Donohue et al. 2009). Moreover, while microfinance is still at a cost disadvantage compared to traditional finance involving larger volumes, good governance and an efficient organization of the credit process have allowed for the cost-covering or even profitable provision of services. This has been achieved by MFIs charging interest rates at levels comparable to those charged for consumer credit by traditional banks in many countries (Rosenberg et al. 2009).

With hindsight, however, the praise of microfinance in the years preceding the global finance crisis also reflected the seeming absence of the downsides associated with traditional finance, most importantly the absence of financial turmoil. This represented a fourth major difference between the industry and traditional banking as the latter was exposed to several financial crises hitting many developing countries and emerging markets in the 1980s and 1990s and undermining the positive growth effects associated with progress in financial development (Winkler 1998; de la Torre 2011). Indeed, before the 
global financial crisis, there had been only one case of microfinance being linked to financial turmoil, namely the Bolivian financial crisis in the late 1990s (Rhyne 2001). By contrast, microfinance was found to be more crisis-resilient than traditional finance (Krauss/ Walter 2009; Galema et al. 2011).

The robustness and stability of microfinance seemed to be an inherent characteristic of the industry reflecting the specific features of its credit technologies and of the target group MFIs serve (Wagner 2012). Solvency shocks were unlikely to have a significant negative effect on portfolio quality as group lending and the unconventional individual lending technology are rather conservative in assessing the clients' ability to pay. Under group lending, borrowers have a clear incentive to carefully screen and monitor each other as the continued access to credit depends on the group's repayment record. The unconventional individual lending technology assesses a client's debt capacity on the basis of current cash flow only, i.e. it neglects any potential revenues the client might gain from the new project being financed. Thus, shocks to clients' income have to be large for materially affecting their ability to serve the loan. Microbusinesses rarely invest in fixed assets providing them with a high degree of flexibility to divert their activities when business slows down. Moreover, MFI clients are usually active in the local economy and hence are less exposed to fluctuations in the global or national economy. Finally, MFI portfolios exhibit a high degree of granularity and diversification (Krauss/Walter 2009), supporting their stability in crises times. With regard to liquidity shocks, microfinance has the advantage of representing mainly short-term lending with weekly or monthly installments. As MFIs fund themselves predominantly long-term via donors and international financial institutions they are not subject to the financial instability challenges of the traditional banking sector which transforms short-term deposits into long-term loans (Diamond/Dybvig 1983).

Against this background, microfinance seemed to be set for an "endless boom" 5 which would raise the degree of financial inclusion. Given the positive impact on clients' incomes that could be expected according to economic theory, it is no surprise that microfinance was seen as a decisive contribution to achieving the millennium goals (Littlefield et al. 2003 ) and, in the end, creating a world without poverty.

\section{Microfinance and subprime lending}

The global financial crisis destroyed many hopes, not only with regard to microfinance but also those associated with the "great moderation" (Bernanke 2004), i.e. a macroeconomic environment characterized by low volatility of growth and inflation. The crisis did not originate in developing and emerging market economies, as it had been the case for most crises in the post Bretton-Woods period. Rather, it originated in the United States, arguably the most advanced economy. At first glance, this suggests that the crisis origin was unrelated to issues discussed in microfinance. However, closer analysis reveals there were at least two characteristics of the crisis that resemble conditions usually associated with financial development in developing and emerging market countries: First, in the years preceding the crisis the United States had run substantial and rising current account deficits: the US had been a net importer of capital, a phenomenon which standard economic theory associates with catching-up economies, i.e. developing and emerging market countries (Obstfeld/Rogoff 1996). Second, the subprime mortgage market that was at the

5 The phrase is borrowed from Enoch/Ötker-Robe (2007). 
very heart of the first phase of the crisis can be regarded as an attempt to expand financial access of low-income and minority US households, i.e. as a form of development finance within the United States. Indeed, subprime lending was most pronounced among lowerincome borrowers and in lower-income neighborhoods (Table 2). In 2002, the subprime share of home equity loans among higher-income households was only 6.7 percent while $14.4 \%$ of lower-income borrowers were using this instrument to acquire a home equity loan. Combining the two crisis characteristics which resemble similarities to conditions in developing economies, Reinhart/Rogoff $(2008,12)$ conclude that the crisis had been preceded by capital inflows to the United States which were channelled to "a developing economy that exists within the United States' own borders”.

\begin{tabular}{lc}
\hline Characteristic & Subprime share of number of home equity loans (percent) \\
\hline Borrower income $^{1}$ & 14.4 \\
Lower & 10.5 \\
Middle & 6.7 \\
Higher & \\
Neighborhood income & \\
Lower & 17.8 \\
Middle & 9.8 \\
Higher & 6.1 \\
\hline
\end{tabular}

$1=$ Lower income means that the borrower's income is less than 80 percent of the median family income of their Metropolitan Statistical Area (MSA).

2 = Lower income means that the median family income in the local Census tract is less than 80 percent of the median of their MSA.

Table 2: Profile of Subprime Mortgage Lending (2002) (Source: Gramlich (2004))

There are several similarities between subprime lending and microcredit (McKee 2008). Both forms of finance have been characterized as a "democratization" of credit (Greenspan 1997; see also Gramlich 2004, and IDB 2008).6 As a result, microfinance and subprime have been endorsed and supported by government or official interventions, in the case of microfinance most importantly via bilateral and multilateral Development Finance Institutions (DFIs). ${ }^{7}$ Moreover, both forms of finance are characterized by higher interest rates than observed in the respective traditional sectors. As a result, microfinance and subprime lending could only thrive in an environment of financial deregulation and liberalization (Helms 2006; Gramlich 2007).

6 Muhammad Yunus often referred to credit as a "human right“.

7 There is some controversy on whether government interventions played a major role in the emergence of the subprime crisis. While Calomiris (2008) claims that these interventions - while not helpful in general - "do not offer an adequate explanation of the ... mortgage mess in the United States", Terberger (2009) argues that implicit US government guarantees were key in attracting private capital to the mortgage market thereby raising systemic risk (see also Kroszner 2008). 
However, there are many differences as well, in particular with regard to subprime lending and microfinance becoming a source of financial instability. First, before becoming subprime borrowers, the respective US households had access to financial services of the formal financial sector. By contrast, microfinance focuses on micro and small enterprises as well as low-income households that have not had access to any formal financial sector services before. Second, although subprime lending involved a disproportionate share of low-income borrowers, the defining characteristic of subprime borrowers was not their income level but their level of risk. Subprime lending involves elevated risk (Gramlich 2004), indicated by a relatively low credit risk score, incidences of delinquencies, foreclosures or bankruptcies in the past, and a debt service-to-income ratio of $50 \%$ or greater (Gorton 2008, 7). ${ }^{8}$ By contrast, the high level of risk is no defining characteristic in microfinance for the very reason that - due to their exclusion from the formal financial sector the level of risk of an individual client is unknown. Moreover, with increasing evidence suggesting that MFIs run high quality loan portfolios, low-income borrowers can be regarded as low-risk clients if appropriate credit technologies for screening and monitoring are employed. ${ }^{9}$

Third, and most importantly, given the high level of risk of subprime borrowers, lending was almost exclusively based on collateral, namely the house that was to be financed. Indeed, in a nutshell, the business model of subprime lending represented a bet on rising house prices (Gorton 2008). By contrast, the specific lending methodologies applied in microfinance focus on clients' cash-flow and personality. ${ }^{10}$ Thus, the business model of microfinance is not a bet, it is an investment in clients.

Overall, this suggests that microfinance is fundamentally different from subprime lending in terms of target group and credit technology (Littlefield 2008). Subprime lending is an instrument to provide risky borrowers, who may be poor at the same time, with access to finance. Microfinance is an instrument to provide financial access for poor borrowers who have been found to show low levels of risk. Accordingly, subprime lending and microfinance have different financial stability implications. The quality of subprime loans is closely linked to changes in asset prices, which are volatile and are prone to boom and bust cycles. By contrast, the quality of microfinance is closely linked to the quality of the underlying analysis of the borrowers.

Securitization spread the risk entailed in subprime lending via markets and Structured Investment Vehicles to the global financial system (IMF 2009). However, the securitization of subprime loans was prone to agency problems and incentive conflicts caused by asymmetric information (Calomiris 2008; Gorton 2008). Thus, at the heart of the US financial crisis was a mixture of causes: an asset price boom, a lending technology based on asset-price developments, and severe agency problems and incentive conflicts in lending itself. This mixture is a familiar one, as it has been the cause of financial crises in many developing and emerging market economies. The element of this crisis which came as a surprise was the place of its origin. The most advanced financial system in the world, considered as the centre of the global financial system, has been showing features that were

8 There is some evidence suggesting that at a late stage of the subprime mortgage boom credit growth was somewhat less pronounced among low-income borrowers than elsewhere (Hershaff et al. 2005).

9 As a result, high interest rates in microfinance largely reflect high transaction costs due to small lot sizes while high interest rates in subprime lending reflected elevated risk.

10 Credit scoring techniques are rarely applied in microfinance institutions (see Schreiner/Dellien 2005). 
thought to be typical of developing and emerging market economies only (Eichengreen 2008). ${ }^{11}$ This leads us to conclude that the subprime crisis was not triggered by lending to a "developing economy that exists within the United States", but by reckless, collateralbased lending as such. Microfinance is the opposite of collateral-based lending. Thus, if mortgage lending to the poor in the United States had been based, at least partly, on cash flow and personality analyses, it would have been unlikely that a subprime boom and bust had emerged. This might not necessarily have guaranteed financial stability. However, the trigger of the financial crisis most likely would have been a different one.

\section{Credit booms and busts - microfinance versus traditional finance}

It is a long-established stylized fact that rapid financial deepening, i.e. a credit boom, is associated with financial turmoil followed by a severe drop in output and employment (IMF 2004). However, the relation between boom and bust is ambiguous. Although there is econometric evidence indicating that rapid credit growth is a highly significant predictor of crises (Schularick/Taylor 2012), it cannot be taken for certain that every credit boom defined as an "episode in which credit to the private sector grows by more than during a typical business cycle expansion" (Mendoza/Terrones 2008, 5) - leads to a crisis (Tornell) Westermann 2002).

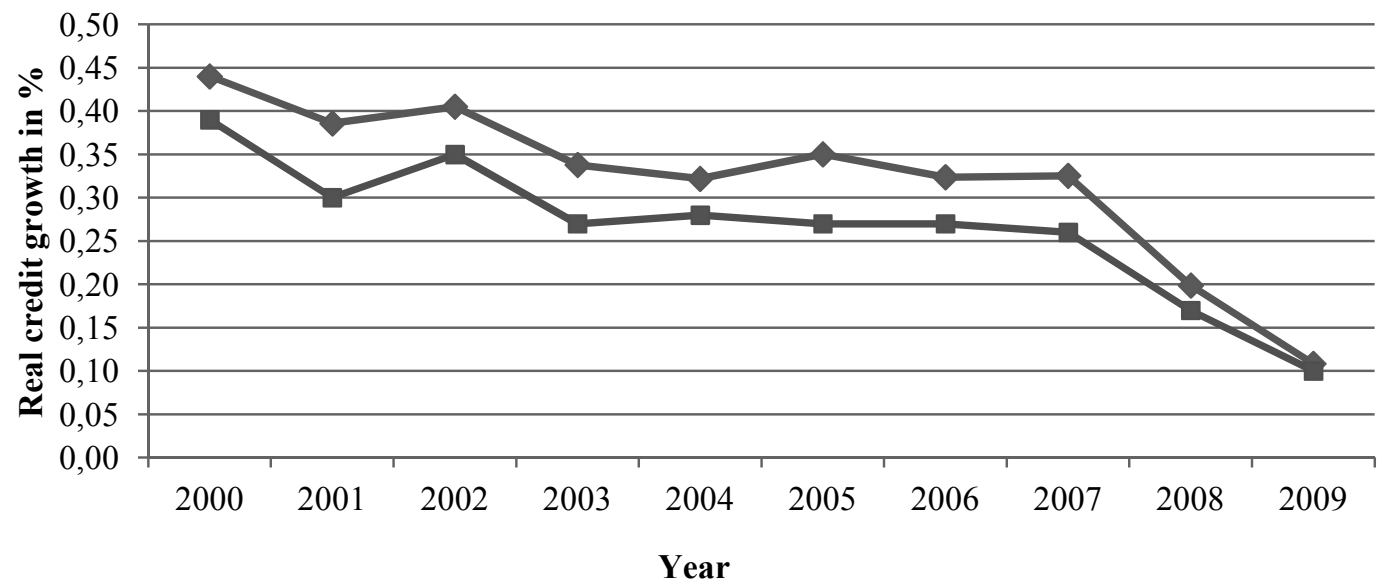

$\sim$ Real credit growth - Mean $\quad-$ Real credit growth - Median

Figure 1: Microfinance institutions - real credit growth, 2000 - 2009 (Source: Wagner/ Winkler (2012))

In the pre-crisis period microfinance recorded spectacular credit growth. Between 2000 and 2007 the loan portfolio of the average MFI grew by more than 30\% p.a. in real terms (Figure 1). However, there were basically no warning signals suggesting an interpretation of this growth as an unsustainable boom that might end in a bust. There simply were no

11 Financial systems of mature economies before World War I, in particular the US, were strongly characterized by these problems, which have been intensively analyzed in the literature (Calomiris/Gorton 1991). Gorton (2008) explicitly draws parallels between panics in the $19^{\text {th }}$ and early $20^{\text {th }}$ century and the current crisis. 
hints that for the first time microfinance was mimicking patterns observed in the traditional banking sector. In addition to the already mentioned reasons for believing in microfinance being inherently crisis-resilient, complacency also reflected the fact that data on credit growth for most MFIs as well as for the microfinance sector as a whole was available for one business cycle only. Thus, it was (and still is) impossible to calculate long-run, country- and institution-specific trends of real credit growth in microfinance. However, without a trend, there is no way to identify a boom as a deviation from trend (Mendozal Terrones 2008).

With hindsight, however, one could have applied more pragmatic approaches for identifying credit booms, as it was done in the earlier literature on financial instability in developing countries. For example, Caprio and Klingebiel (1996) suggest to classify credit growth as excessive and hence as a boom when the growth rate is twice as high as GDP growth. Kraft and Jankov (2005), studying credit growth in the early transition period in Eastern Europe, implicitly refer to a credit boom when annual real credit growth is above 25 percent.

We apply those pragmatic benchmarks for the pre-crisis period for countries where data is available for the traditional banking as well as for the microfinance sector (Table 3). The evidence shows that credit growth rates in microfinance passed the benchmarks much more often than credit growth rates in the traditional banking sector. Moreover, as shown in Wagner (2012), credit growth rates in the microfinance sector in most countries were substantially higher than in the traditional banking sector in the pre-crisis period.

\begin{tabular}{|c|c|c|c|c|c|c|c|c|}
\hline & 2000 & 2001 & 2002 & 2003 & 2004 & 2005 & 2006 & 2007 \\
\hline $\begin{array}{l}\text { Total number of countries } \\
\text { included in the sample }\end{array}$ & 41 & 45 & 57 & 71 & 77 & 81 & 82 & 82 \\
\hline $\begin{array}{l}\text { Number of countries with real } \\
\text { credit growth in the traditional } \\
\text { banking sector }>25 \%\end{array}$ & 3 & 3 & 4 & 12 & 15 & 11 & 18 & 29 \\
\hline $\begin{array}{l}\text { Number of countries with real } \\
\text { credit growth in the microfinance } \\
\text { sector }>25 \%\end{array}$ & 27 & 25 & 41 & 40 & 40 & 41 & 40 & 42 \\
\hline $\begin{array}{l}\text { Number of countries with real } \\
\text { credit growth in the traditional } \\
\text { banking sector twice as high as } \\
\text { real GDP growth }\end{array}$ & 23 & 20 & 30 & 42 & 51 & 57 & 54 & 58 \\
\hline $\begin{array}{l}\text { Number of countries with real } \\
\text { credit growth in the microfinance } \\
\text { sector twice as high as real GDP } \\
\text { growth }\end{array}$ & 35 & 37 & 50 & 56 & 59 & 68 & 59 & 64 \\
\hline
\end{tabular}

Table 3: Credit growth - traditional banking sector and microfinance (Source: Wagner/ Winkler (2011)) 
However, even if this evidence had been available before the crisis, one could have argued that microfinance credit growth is benign as it largely reflects a catching-up phenomenon. Given the lack of access to formal financial sector services for an estimated one or two billion people (Armendáriz/Morduch 2010), rapid micro credit growth appeared to be sustainable and much more bust-resistant than credit expansion in the traditional banking sector. ${ }^{12}$ Supporting this view, Gonzalez (2010) presents evidence based on data covering the period 2000-2008 indicating that portfolio quality of MFIs is likely to deteriorate only when growth rates become extremely high - surpassing $200 \%$ p.a. According to Gonza$l e z$, the microfinance danger zone starts at credit growth rates of about $60 \%$ p.a., with more caution to be exercised in countries with a high penetration ratio, i.e. where the number of borrowers from MFIs exceeds $10 \%$ of the total population. Overall, the argument that speed might kill (Kraft/Jankov 2005), i.e. that rapid credit growth might end in a bust, irrespective of the level of financial development and market penetration, was severely downplayed.

Already at an early stage of the global financial crisis, however, anecdotal evidence from practitioners (Centre for the Study of Financial Innovation 2008, Littlefield/Kneiding 2009) indicated that MFIs were strongly affected. Since then, anecdotal evidence has been increasingly supported by econometric analysis. Di Bella (2011) provides evidence standing in sharp contrast to earlier results on microfinance being rather decoupled from general economic cycles. By way of including the data on the crisis years 2008 and 2009, di Bella finds MFI performance to be significantly correlated with domestic and international financial and economic conditions. Wagner and Winkler (2012) show that microfinance has adopted cyclical characteristics of the traditional banking sector. MFIs that recorded higher credit growth in the boom period, and at the same time were tapping domestic and international capital markets for funding more aggressively, saw a more pronounced decline in credit growth in the crisis, i.e. in 2008/2009. However, the authors' results also indicate that a decline in credit demand contributed to the fall in MFI credit growth in the crisis period: lower GDP growth in the course of the global recession, food price inflation, and the decline in remittances represent important factors in explaining the fall in MFI credit growth in the crisis.

The new vulnerability of microfinance seems to reflect supply and demand factors. But why have they become more relevant compared to the emerging market crises in the 1990s? Several arguments point to changes in the market environment MFIs and their clients operate in, and these might explain the decline in crisis resilience.

On the supply side, microfinance institutions (MFIs) are no longer isolated from mainstream finance because they have increasingly turned to domestic and international capital markets, commercial banks, and micro investment vehicles for raising funds to foster credit growth (El-Zoghbi et al. 2011). This holds for all institutional types, with the exception of credit cooperatives. These new funding opportunities that have become available to MFIs since the late 1990s certainly have shown their virtues, even in the crisis period, as there were only few cases of MFIs running into substantial liquidity problems in the course of the crisis (Gonzalez 2011). However, pre-crisis credit growth would not have

12 In this context, Lützenkirchen/Weistroffer (2012) refer to the "absurd gap" hypothesis, as it "absurdly" assumes that all people without access to formal financial sector services demand such services, in particular credit. See also Anand/Rosenberg (2008). 
been possible at the scale observed without the new funding sources. This holds in particular for the larger and fast growing institutions.

The rising availability of funding was accompanied by rising levels of competition within the sector due to an expansion of existing institutions and networks, and due to the entry of new players. Competition has direct implications for the stability properties of the credit technologies MFIs rely upon. Dynamic incentives, i.e. the prospect of receiving a new loan when the old one has been fully repaid on time, play a key role in explaining the low risk costs MFIs incur (Armendáriz/Morduch 2010). ${ }^{13}$ However, these incentives only work in a financial sector environment where the major competitor of an MFI is the informal financial sector with unreliable and expensive services. While this environment fairly characterized most microfinance sectors in the 1980s and 1990s, rising competition (Assefa et al. 2010) makes it more difficult to successfully apply these incentives. Clients have new borrowing alternatives to the MFI they received a loan from as other MFIs offer loans at similar conditions. Moreover, in a more competitive environment and with financial inclusion becoming a major goal of many MFIs the conservative credit technologies were applied in a less rigorous way (Chen et al. 2010), mimicking patterns observed in the traditional banking sector in boom periods (Arcalean 2007; Jiménez 2008). In addition, MFIs engaged in substantial hiring efforts to accommodate the pre-crisis credit boom (Zeitinger 2010). However, inexperienced loan officers have been found to accept riskier clients (Behr et al. 2011) adding another dimension of vulnerability to the business model of MFIs (Centre for the Study of Financial Innovation 2008). The vulnerabilities materialized when financial and macroeconomic conditions deteriorated in the wake of the crisis. As a result, substantial problems of over-indebtedness and multiple borrowing emerged (Kappel et al. 2011).

Finally, it can be argued that the pre-crisis period of strong growth and catching-up in many developing and emerging market countries was accompanied by a rising degree of integration of micro and small businesses into the national economy. While this had been beneficial to firm growth, it also made those businesses more vulnerable to national and global financial shocks. ${ }^{14}$ In addition, some MFIs diverted from the original target group of (informal) microbusinesses by increasingly turning to (consumer) lending to salaried workers. However, the latter are by definition highly vulnerable to income shocks, including food price inflation, as they lack the flexibility to generate extra income out of which the loan can be served. Gonzalez (2011) presents evidence indicating that the rise in vulnerability largely reflects the experience of MFIs that have engaged in consumer lending.

Overall, existing evidence suggests that microfinance has become more exposed to credit cycle phenomena because over the last decade there have been changes in market conditions in which MFIs and their target group operate. These changes have in common that they point towards a higher degree of integration; MFIs are more closely integrated into financial markets, and the target group is more integrated into the domestic economy. While this has a positive effect on income and growth of MFIs and their clients in good times, it makes them more vulnerable in crisis times. Furthermore, a rising degree of com-

13 Clients repay because they will have a demand for loans in the future. As long as the MFI is the only available source for reliable funding at reasonable conditions they will repay in order to avoid searching for funds in the informal financial sector that is less reliable and more expensive.

14 Lützenkrichen/Weistroffer (2012) report that MFIs serving customers at the upper end of the target group were most affected by the crisis. 
petition among MFIs has eroded some of the stability enhancing features that characterize microfinance credit technologies.

\section{Summary and conclusions}

Microfinance certainly has been the most important instrument in development finance to foster financial inclusion of poor households and microenterprises. Driven by views arguing that access to finance provides major benefits to the target group in terms of income and poverty alleviation, microfinance institutions have expanded credit at a rapid pace. This trend came to an end after the financial crisis marking the first global credit cycle in the history of microfinance: a credit boom was followed by a severe decline in growth and portfolio quality.

In this paper we argue that the new vulnerability of microfinance to financial turmoil does not reflect phenomena observed in subprime lending which triggered the global financial crisis. Indeed, microfinance is based on credit technologies that differ fundamentally from those applied in subprime lending. The quality of subprime loans is closely linked to changes in asset prices, which are volatile and are prone to boom and bust cycles. By contrast, the quality of microfinance is closely linked to the quality of the underlying analysis of borrowers. However, the very goal of fostering financial inclusion has led to more integration of microfinance into domestic and international financial systems and raised competition within the microfinance sector. Moreover, the profile of MFI clients changed due to favourable economic conditions in the pre-crisis period and to a wider definition of the target group MFIs employ. Both trends challenge the relative crisis-resilience of microfinance observed in the emerging market crises of the 1990s as the new trends undermine some assumptions MFIs have relied upon when lending to the target group: clients are less constrained by dynamic incentives, and they are more exposed to domestic shocks while their flexibility to respond to them has declined. Moreover, MFIs themselves - in an attempt to provide financial access to as many poor households and poor people as possible - have engaged in lending practices that characterize traditional banking in boom periods: a reduction of lending standards in an environment characterized by optimism and the expectation of strong growth.

Does this mean that we should turn back the clock and require the industry to refocus again on target groups that are still relatively isolated from domestic and international economic developments? Shall we reduce competition among MFIs and roll back their integration into domestic and international capital markets? We would not want to draw such conclusions. However, there seems to be a need for adaption to the new business climate of microfinance. Credit technologies are to be modified, and MFI governance as well as the organisation of the credit process have to address the new financial stability challenges microfinance is exposed to. Applying a more conservative view on the sustainability of credit growth rates would be a first step to signal that the industry has learnt the lesson which the traditional banking sector had to learn in the past: there can be too much credit. This lesson holds regardless of whether commercial banks fight for market shares or whether well-intended MFIs aim at fostering financial inclusion. 


\section{References}

Anand, M./Rosenberg, R. (2008): Are We Overestimating Demand for Microloans?, CGAP Brief, April, Washington D.C.

Arcand, J.-L./Berkes, E./Panizza, U. (2012): Too much finance?, IMF Working Paper No. 12/161, Washington D.C.

Arcalean, C., et al. (2007): The Causes and Nature of the Rapid Growth of Bank Credit in the Central-Eastern and South-Eastern European Countries, in: Enoch, C./Ötker-Robe, I. (Eds.): Rapid Credit Growth in Central and Eastern Europe, Houndmills, pp. 13-46.

Armendáriz, B./Morduch, J. (2010): The Economics of Microfinance,Cambridge/London.

Assefa, E./Hermes, N./Meesters, A. (2010): Competition and performance of Microfinance Institutions, under http://www.microfinancegateway.org/gm/document-1.1.9499/competition\%20and $\% 20$ performance\%20of\%20MFIs.pdf (accessed 06.2011).

Behr, P./Entzian, A./Gütler, A. (2011): How do lending relationships affect access to credit and loan conditions in microlending?, in: Journal of Banking and Finance, Vol. 35, pp. 2168-2178.

Bernanke, B.S. (2004): The Great Moderation, Remarks at the meetings of the Eastern Economic Association, Washington, DC, February 20, under http://www.federalreserve.gov/boarddocs/spe eches/2004/20040220/default.htm (accessed 20.9.2012)

Bernanke, B.S. (2012): Some Reflections on the Crisis and the Policy Response, Remarks at the Russell Sage Foundation and The Century Foundation Conference on "Rethinking Finance", New York, April 13, under http://www.federalreserve.gov/newsevents/speech/bernanke20120413a. htm (accessed 15.9.2012).

Calomiris, C.W./Gorton, G. (1991): The Origins of Banking Panics, in: Hubbard, R.G. (ed.): Financial Markets and Financial Crises, Chicago, pp. 109-173

Calomiris, C.W. (2008): The Subprime Turmoil: What's Old, What's New, and What's Next, in: "Maintaining Stability in a Changing Financial System", Federal Reserve Bank of Kansas City Symposium Proceedings.

Caprio, G./Klingebiel, D. (1996): Bank Insolvency: Bad Luck, Bad Policy, or Bad Banking?, in: Annual Bank Conference on Developing Economies, World Bank, Washington, pp. 79-114.

Cecchetti, S.G./Kharroubi, E. (2012): Reassessing the impact of finance on growth, BIS Working Papers No. 381, Basel.

Centre for the Study of Financial Innovation (2008): Microfinance Banana Skins Report 2008: Risk in a booming industry, under http://www.citi.com/citi/microfinance/data/news080303b.pdf (accessed 08.2011).

Chen, G./Rasmussen, S./Reille, X. (2010): Growth and Vulnerabilities in Microfinance, CGAP Focus Note No. 61, Washington D.C.

Cull, R./Demirguc-Kunt, A./Morduch, J. (2008): Microfinance Meets the Market, World Bank Policy Research Working Paper No. 4630, Washington D.C.

De la Torre, A./Feyen, E./Ize, A. (2011): Financial Development - Structure and Dynamics, World Bank Policy Research Working Paper No. 5854, Washington D.C.

Diamond, D.W./Dybvig, P.H. (1983): Bank Runs, Deposit Insurance, and Liquidity, in: Journal of Political Economy, Vol. 91, No. 3, pp. 401-419.

Di Bella, G. (2011): The Impact of the Global Financial Crisis on Microfinance and Policy Implications, IMF Working Paper 11/175, Washington DC. 
El-Zoghbi, M./Gahwiler, B./Lauer, K. (2011): Cross-Border Funding of Microfinance. CGAP Focus Note No. 70, CGAP, Washington DC.

Enoch, C./Ötker-Robe, I. (2007): Rapid Credit Growth in Central and Eastern Europe: endless boom or early warning?, Houndmills.

Eichengreen, B. (2008): The U.S. as an Emerging Market, under http://emlab.berkeley.edu/ eichengr /united_states_emerging_9-16-08.pdf (accessed 21.09.2012).

Galema, R./Lensink, R./Spierdijk, L. (2011): International diversification and Microfinance, in: Journal of International Money and Finance, Vol. 30, pp. 507-515.

Gonzalez, A. (2010): Is microfinance growing too fast?, Mix Data Brief No. 5, Washington D.C.

Gonzalez, A. (2011): Lessons for Strengthening Microfinance Institutions through Financial Crises, Fluctuations in Food and Fuel Prices and Other Major Risks, Micro Banking Bulletin, August 2011.

Gorton, G. (2008): The Panic of 2007, NBER Working Paper No. 14358, Cambridge MA.

Gramlich, E.M. (2004): Subprime Mortgage Lending: Benefits, Costs, and Challenges, Remarks at the Financial Services Roundtable Annual Housing Policy Meeting, May 21, Chicago IL.

Gramlich, E.M. (2007): Subprime Mortgages - America's Latest Boom and Bust, The Urban Institute.

Greenspan, A. (1997): Consumer Credit and Financial Modernization, Remarks at the Economic Development Conference of the Greenlining Institute, October 11, San Francisco CA.

Helms, B. (2006): Access for all, Building Inclusive Financial Systems, The World Bank, Washington D.C.

Hershaff, J./Wachter S./Russo K. (2005): Subprime lending: Neighbourhood Patterns Over Time, Paper presented at the Federal Reserve System's Fourth Community Affairs Research Conference "Promises \& Pitfalls", April 7-9, Washington D.C.

IMF (2004): Are Credit Booms in Emerging Markets a Concern? World Economic Outlook Chapter IV, pp. 147-166.

IMF (2009): Lessons of the Global Crisis for Macroeconomic Policy, February 19, Washington DC.

Inter-American Development Bank (2008): IDB Group supports Guatemalan bank's expansion into microfinance, News release, 10 December, Washington D.C.

Jiménez Zambrano, G./Ongena, S./Peydrò, J.L./Saurina, J. (2008): Hazardous times for monetary policy: What do twenty-three million bank loans say about the effects of monetary policy on credit risk-taking? Banco de España Working Paper No. 083, Madrid.

Kappel, V./Krauss A./Lontzek, L. (2011): Over-indebtedness and Microfinance: Constructing an Early Warning Index, Zurich: Responsibility, CMEF and Triodos Investment Management (ed.).

Karlan, D./Morduch, J. (2012): Access to finance, in: Rodrik, D./Rosenzweig, M. (eds.): Handbook of Development Economics, Vol. 5, pp. 4703-4784.

King, R.G./Levine, R. (1993): Finance and Growth: Schumpeter Might Be Right, in: Quarterly Journal of Economics, Vol. 107, pp. 717-737.

Kraft, E./Jankov, L. (2005): Does speed kill? Lending booms and their consequences in Croatia, in: Journal of Banking and Finance, Vol. 29, pp. 105-121.

Krauss, N./Walter, I. (2009): Can Microfinance Reduce Portfolio Volatility?, in: Economic Development and Cultural Change, Vol. 58, No. 1, pp. 85-110. 
Kroszner, R.S. (2008): The Community Reinvestment Act and the Recent Mortgage Crisis, Speech at the Confronted Concentrated Poverty Policy Forum, Board of Governors of the Federal Reserve System, December 3, Washington D.C.

Littlefield, E./Hashemi, S.M./Morduch, J. (2003): Is Microfinance an Effective Strategy to Reach the Millennium Development Goals?, CGAP Focus Note 24, Washington D.C.

Littlefield, E. (2008): Promoting Financial Stability and Economic Inclusion, Opening remarks at the International Association of Deposit Insurers (IADI) 7th Annual Conference, Hosted by the FDIC, October 30, Washington, D.C.

Littlefield, E./Kneiding, C. (2009): The Global Financial Crisis and Its Impact on Microfinance. CGAP Focus Note 52. Washington, DC.

Lützenkirchen, C./Weistroffer, C. (2012): Microfinance in evolution. An industry between crisis and advancement, DB Research, September, under http://www.dbresearch.de/MAIL/DBR_INTERNE T_DE-PROD/PROD0000000000294314.pdf (accessed 20.09.2012).

McKee, K. (2008): Meditations on the U.S. Subprime Crisis, The Microfinance Gateway, March 2008, under http://www.microfinancegateway.org/p/site/m/template.rc/1.26.9143/ (accessed 20.09.2012)

Mendoza, E./Terrones, M. (2008): An Anatomy of Credit Booms: Evidence From Macro Aggregates in Micro Data, NBER Working Paper 14049, Cambridge.

Merton, R.C./Bodie, Z. (1995): A Conceptual Framework for Analysing the Financial Environment, in: Crane, D.B. (ed.): The global financial system: a functional perspective, Boston, pp. 3-32.

O’Donohoe, N.P., et al. (2009): Shedding Light on Microfinance Equity Valuation: Past and Present, CGAP Occasional Paper No. 14, CGAP and J.P. Morgan, Washington D.C.

Obstfeld, M./Rogoff, K. (1996): The Intertemporal Approach to the Current Account, NBER Working Papers No. 4893, Cambridge MA.

Reinhart, C.M./Rogoff, K. (2008): Is the 2007 U.S. Sub-Prime Financial Crisis So Different? An International Historical Comparison, NBER Working Paper No. 13761, Cambridge MA.

Rhyne, E. (2001): Commercialization and Crisis in Bolivian Microfinance, under http://www.microf inancegateway.org/gm/document1.9.28329/28001_file_commercialization_and_crisis_4.pdf (accessed 20.09.2012).

Rosenberg, R./Gonzalez, A./Narain, S. (2009): The New Moneylenders: Are the Poor Being Exploited by High Microcredit Interest Rates? CGAP Occasional Paper No. 15, Washington D.C.

Rousseau, P.L./Wachtel, P. (2011): What Is Happening To The Impact Of Financial Deepening On Economic Growth?, in: Economic Inquiry, Vol. 49, No. 1, pp. 276-288.

Schreiner, M./Dellien, H. (2005): Credit Scoring, Banks, and Microfinance: Balancing "High-Tech" with "High-Touch", in: Microenterprise Development Review, Inter-American Development Bank, Vol. 8, No. 2, pp. 1-5.

Schularick, M./Taylor, A.M. (2012): Credit Booms Gone Bust: Monetary Policy, Leverage Cycles, and Financial Crises, 1870-2008, in: American Economic Review, Vol. 102, No. 2, pp. 10291061.

Terberger, E. (2009): Subprime-Krise, strukturierte Finanzierung und die Förderung der Mikrokreditvergabe, DIW Vierteljahreshefte, Vol. 78, No. 1, pp. 40-55.

Terberger, E. (2012): The Microfinance Approach: Does it deliver on its promise?, in: Die Unternehmung - Swiss Journal of Business Research and Practice, Vol. 66, No. 4, pp. 358-370.

Tornell, A./Westermann, F. (2002): Boom-Bust Cycles in Middle Income Countries: Facts and Explanation, NBER Working Papers 9219, Cambridge MA. 
Trichet, J.C. (2010): What role for finance?, Lecture at the Universidade Nova de Lisboa, Lisbon, May 6, under www.ecb.int (15.9.2012).

Wagner, C. (2012): From Boom to Bust: How different has Microfinance been from Traditional Banking?, in: Development Policy Review, Vol. 30, No. 2, pp. 187-210.

Wagner, C./Winkler, A. (2011): Financial Stability Challenges in Microfinance - Drivers of the PreCrisis Credit Boom, Paper presented at the 24th Australasian Finance and Banking Conference 2011, Sydney, under http://ssrn.com/abstract=1916633 (accessed 10.2011).

Wagner, C./Winkler, A. (2012): The vulnerability of microfinance to financial turmoil - evidence from the global financial crisis, Paper presented at the 16th International Conference on Macroeconomic Analysis and International Finance, Rethymno, Crete, Greece, under http://econ omics.soc.uoc.gr/macro/docs/Year/2012/papers/paper_2_74.pdf (accessed 20.9.2012).

Winkler, A. (1998): The Dual Role of Financial Markets in Economic Development: Engine of Growth and Source of Instability, IPC Working Paper No. 18, Frankfurt am Main.

Winkler, A. (2009): The financial crisis - a development finance perspective, Inaugural lecture, Frankfurt School of Finance \& Management, unpublished mimeo.

World Bank (2008): Finance for All? Policies and Pitfalls in Expanding Access, Washington D.C.

Charlotte Wagner, Dipl. Kffr., is Research Associate at the Centre for Development Finance at the Frankfurt School of Finance \& Management.

Adalbert Winkler, Dr., is Professor for International and Development Finance and Academic Head of the Centre for Development Finance at the Frankfurt School of Finance \& Management.

Address: Frankfurt School of Finance \& Management, Finance Department, Sonnemannstr. 9-11, 60314 Frankfurt am Main 